\title{
Chemical Composition, Antioxidant Activities of the Essential Oil of Mentha pulegium L, South East of Algeria
}

\author{
Ouakouak H. ${ }^{2 \star}$, Chohra M. ${ }^{1}$, Denane M. ${ }^{1}$ \\ ${ }^{1}$ Laboratoire Central De Police Scientifique/Chateauneuf, Direction De La Police Scientifique Et \\ Technique Ben Aknoun, Alger, Algerie \\ ${ }^{2}$ University of El-Oued, VTRS Laboratory, B.P.789, 39000, El Oued, Algeria \\ *E-mail address: hamza39ouakouak@gmail.com
}

Keywords: Mentha pulegium; Lamiaceae; pulegone; essential oil; antioxidant activity; GC/GC-MS; $\mathrm{DPPH}$.

\begin{abstract}
Aerial parts of Mentha pulegium L. collected from south east of Algeria (Reguiba, El-Oued) possessed an essential oil in 2.34\% (v/w) yield. GC and GC-MS analysis of the oil revealed recognition of Thirty-seven compounds, representing 95.02\% (area percent) of the total oil composition. Oil was rich in Oxygenated hydrocarbons, exhibited higher percentage of Pulegone (46.31\%) followed by Piperitenone (23.3\%), Menthone (6.2\%) and Limonene (4.7\%). The antioxidant activity by DPPH free radical scavenging bioassay $\left(\mathrm{IC}_{50}=157 \mu \mathrm{l} / \mathrm{ml}\right)$.
\end{abstract}

\section{INTRODUCTION}

The Lamiaceae family (Labiatae) is one of the largest and most distinctive families of flowering plants, with about 220 genera and almost 4000 species worldwide. It is one of the most diverse and widespread plant families in terms of ethnomedicine [1].

Mentha is an important genus of the family containing 25 to 30 aromatic herbs of difficult taxonomic classification due to a great variability in their morphological characters and frequent hybridization. The aromatic Mentha herbs are perennials found in damp or wet places. Members of this genus are the most important sources of essential oil production in the world. It has been estimated that the annual production of oils from the three Mentha species, namely, peppermint $(M$. piperita L.), cornmint (M. arvensis L.) and spearmint (M. spicata), is in excess of 23,000 metric tons with a value exceeding $\$ 400$ million. This makes them the most economically important essential oils produced [2].

Mentha pulegium L. is a perennial plant of the Lamiaceae family, commonly known as pennyroyal is an aromatic perennial herbaceous plant reaching up to $40 \mathrm{~cm}$. M. pulegium grows widely in humid and damp areas and water banks in many parts of the Eurasian territories [3], Mentha pulegium (pennyroyal, known in North Africa as "Fleyou") is a native species of the Mediterranean basin (Europe and North Africa) and also found in Asia Minor and Near East regions $[4]$.

Recently, the essential oils and various extracts of plants have provoked interest as sources of natural products. They have been screened for their potential uses as alternative remedies for the treatment of many infectious diseases and the preservation of foods from the toxic effects of oxidants. Particularly, the antimicrobial activities of plant oils and extracts have formed the basis of many applications, including raw and processed food preservation, pharmaceuticals, alternative medicine and natural therapies [5,6]. Following questions about the quality and safety of foods, only selected food additives are allowed [7]. Because of the possible toxicities of the synthetic antioxidants, butylated hydroxyanisole (BHA) and butylated hydroxytoluene (BHT), increasing attention has been directed toward natural antioxidants [8]. 
The mint species have a great importance, both medicinal and commercial. Indeed, leaves, flowers and stems of Mentha spp. are frequently used in herbal teas or as additives in commercial spice mixtures for many foods to offer aroma and flavor $[9,10]$.

Mentha pulegium oil has been used in traditional medicine, food processing, perfumery, pharmaceutical products and as an insect repellent [4,11]. It is also known for its carminative, antispasmodic, antiseptic, diaphoretic and emmenagogue properties [4,11].

Previous studies have shown that oil of $M$. pulegium varies within and among geographic-climatic zones $[12,13]$. Pulegone (17.5-70.2\%) constitutes the major compound of this oil $[12,14]$.

This study to identify the chemical composition of the essential oil of the mint commonly used in folk medicine Algerian folkloric medicine (M. pulegium), as well as their antioxidant.

\section{MATERIALS AND METHODS}

\subsection{Plant material collection and oil extraction}

Flowering aerial parts of plant were collected from south east of Algeria (Reguiba, El-Oued) (latitude of $33^{\circ} 33^{\prime}$ to $33^{\circ} 34^{\prime}$ North and longitude of $6^{\circ} 42^{\prime}$ to $6^{\circ} 43^{\prime}$ East at an elevation of about $59 \mathrm{~m}$ above sea level), Algeria in August, 2014. The plant was identified in the book [15] and National Institute of Plant Protection Harrach, Algeria. $100 \mathrm{~g}$ of dried plant parts were cut in small pieces and the essential oil was obtained by hydrodistillation in $300 \mathrm{~mL} \mathrm{H}_{2} \mathrm{O}$ for $4 \mathrm{~h}$ using Clevenger's apparatus [16]. The oil content (v/w \%) was estimated on dry weight basis. The essential oil obtained was dehydrated over anhydrous sodium sulphate and was stored at $4{ }^{\circ} \mathrm{C}$ for further study.

\subsection{Gas chromatography analysis (GC-FID)}

The gas chromatographic analyzes were performed using a Agilent Technologies 7890A Network system gas chromatograph equipped with a non-polar column HP5MS (30 x $0.25 \mathrm{~mm}$ d.i., Film thickness $0.25 \mu \mathrm{m}$ ) and a flame ionization detector (FID).

The analytical conditions were as follows: the essential oils were diluted with hexane at about $1 / 10$. The flow of the carrier gas helium was kept constant at $1 \mathrm{ml} / \mathrm{min}$. The temperatures of injector and detector were 250 and $280^{\circ} \mathrm{C}$, respectively. The injected volume was $1 \mu \mathrm{L}$ with a split of $1 / 20$. The temperature was maintained at $60{ }^{\circ} \mathrm{C}$ for $5 \mathrm{~min}$, then increased by a gradient of $3{ }^{\circ} \mathrm{C} / \mathrm{min}$ to reach $250^{\circ} \mathrm{C}$; this temperature was kept constant for $5 \mathrm{~min}$.

A series of n-alkanes from $\mathrm{C}_{5}$ to $\mathrm{C}_{28}$ was injected under the same analytical conditions as the samples, for the measurement of retention indices following Van den Dool and Kratz [17].

\subsection{Gas chromatography-mass spectrometry(GC-MS)}

The volatile compounds were analyzed by coupled to mass spectrometry brand Hewlet Packard 5973A, equipped with an non-polar capillary column (HP5MS, $30 \mathrm{~m} \mathrm{x} 0.25 \mathrm{~mm}$, phase thickness: $0.25 \mu \mathrm{m})$. GC-MS spectra were obtained using the following conditions: He (helium) as carrier gas at flow rate of $1 \mathrm{~mL} / \mathrm{min}$; split mode1: $20 ; 1 \mu \mathrm{L}$ as injected volume; $250{ }^{\circ} \mathrm{C}$ as injection temperature. The oven temperature program was $60{ }^{\circ} \mathrm{C}$ for $5 \mathrm{~min}$ increasing at $3{ }^{\circ} \mathrm{C} / \mathrm{min}$ toward $250^{\circ} \mathrm{C}$ and held at $250^{\circ} \mathrm{C}$ during 10 min the ionization mode used was electronic impact at $70 \mathrm{eV}$. Most constituents were identified by comparison of their GC linear retention indices (RI), determined with reference to a homologous series of $\mathrm{C}_{5}-\mathrm{C}_{28} \mathrm{n}$-alkanes. The Identification was Confirmation by comparison of the mass spectral with those stored in the MS database (National Institute of Standards and Technology NIST08 and Wiley libraries) and also by comparison with mass spectra from literature data [17]. The percentage composition was calculated from the summation of peak areas of the total oil. 


\subsection{DPPH (2, 2'- diphenyl-1-picrylhydrazyl) radical scavenging bioassay}

In this method, the antioxidant activity of the essential oil extract is evaluated in term of the capacity to scavenging free radicals of DPPH formed, according to a method described by [18]. A solution of $4 \mathrm{mg}$ of the radical DPPH dissolved in $100 \mathrm{~mL}$ of methanol was prepared. Then $2 \mathrm{~mL}$ of this solution was reacted with $1 \mathrm{~mL}$ of oil diluted extract (dissolved in methanol). The mixture was incubated in dark room for $30 \mathrm{~min}$ at room temperature. The absorbance was measured at $517 \mathrm{~nm}$ with Helios Omega UV/VIS Thermo Scientific Merk and Co. Spectrophotometer. The percentage inhibition activity was calculated by Eq. (1):

$$
I \%=\left(\frac{A_{0}-A_{t}}{A_{0}}\right) \times 100
$$

where $\mathrm{A}_{0}$ is the absorbance of the control sample (without essential oil) and At the absorbance of the extract with DPPH at $30 \mathrm{~min}$ [19]. Tocopherol (VitE) and BHA (Butylated hydroxyanisole) and BHT (Butylated hydroxy toluene) was used as reference and all analyses. Sample concentration providing $50 \%$ inhibition $\left(\mathrm{IC}_{50}\right)$ was obtained plotting the inhibition.

\section{RESULTS AND DISCUSSION}

The essential oil of $M$. pulegium was extracted by hydrodistillation of the aerial parts and the percentage yield was calculated to be $2.34 \%(\mathrm{v} / \mathrm{w})$. The oil was light yellow in colour, soluble in methanol, ether and ethanol, and having a characteristic strong fragrance of mint.

\subsection{Results of GC-MS analysis}

The identified constituents with their respective percentages and Kovat's indices are summarized in Table 1. GC and GC-MS analysis of the oil revealed recognition of thirty seven major and minor compounds, representing $95.02 \%$ (area percent) of the total oil composition. Oil was rich in Oxygenated hydrocarbons, exhibited higher percentage of Pulegone $(46.31 \%)$ followed by Piperitenone $(23.3 \%)$ and Menthone $(6.2 \%)$. were reported as major constituents while $p$ Cymene $(0.1 \%)$, 3-octanone $(0.11 \%)$, Z- $\beta$-Ocimene $(0.11 \%)$, Terpinen-4-ol $(0.12 \%)$, Octan-3-ylacetate $(0.15 \%)$ and $\beta$-Myrcene $(0.25 \%)$ were turned out in lower amounts. The oil was characterized by higher content of oxygenated monoterpenes $(80.24 \%)$ followed by $7.24 \%$ of monoterpene hydrocarbons and $3.73 \%$ of sesquiterpene hydrocarbons.

Table 1. Chemical composition of Mentha pulegium L essential oil.

\begin{tabular}{c|c|c}
\hline Components & Kovat's indices & \% Content \\
\hline$\alpha$-Thujene & 918 & $\operatorname{tr}$ \\
$\alpha$-Pinene & 928 & 0.62 \\
Camphene & 938 & $\operatorname{tr}$ \\
Sabinene & 963 & 0.9 \\
$\beta$-Pinene & 966 & 0.2 \\
Octan-3-ol & 970 & $\operatorname{tr}$ \\
3-octanone & 974 & 0.11 \\
$\beta$-Myrcene & 981 & 0.25 \\
$\alpha$-Terpinene & 1011 & $\operatorname{tr}$ \\
Limonene & 1015 & 4.7 \\
p-Cymene & 1017 & 0.1 \\
$\beta$-Phellandrene & 1019 & $\operatorname{tr}$ \\
1,8-Cineol & 1021 & 0.3 \\
$(Z)-\beta$ - Ocimene & 1027 & 0.11
\end{tabular}




\begin{tabular}{|c|c|c|}
\hline$\gamma$-Terpinene & 1052 & $\operatorname{tr}$ \\
\hline Linalool & 1091 & $\operatorname{tr}$ \\
\hline Octan-3-yl-acetate & 1123 & 0.15 \\
\hline cis-Limonene oxide & 1128 & 0.41 \\
\hline trans-Limonene oxide & 1133 & 0.31 \\
\hline Menthone & 1152 & 6.2 \\
\hline Neomenthol & 1158 & 0.22 \\
\hline Menthofurane & 1162 & $\operatorname{tr}$ \\
\hline Terpinen-4-ol & 1170 & 0.12 \\
\hline trans -piperitol & 1202 & $\operatorname{tr}$ \\
\hline Carveol & 1221 & $\operatorname{tr}$ \\
\hline Pulegone & 1229 & 46.41 \\
\hline Carvone & 1234 & 1.5 \\
\hline Piperitone & 1244 & 2.63 \\
\hline Thymol & 1282 & 0.18 \\
\hline Isomenthone & 1288 & 3.7 \\
\hline Piperitenone & 1337 & 23.3 \\
\hline$\beta$-Caryophyllene & 1423 & $\operatorname{tr}$ \\
\hline$\alpha$-Humulene & 1448 & 0.62 \\
\hline Germacrene D & 1478 & $\operatorname{tr}$ \\
\hline$\gamma$-Cadinene & 1508 & $\operatorname{tr}$ \\
\hline$\delta$ - Cadinene & 1517 & 1.93 \\
\hline$\alpha$ - Calacorene & 1538 & 1.18 \\
\hline \multicolumn{2}{|l|}{ Total identified } & 95.02 \\
\hline Class composition of the oil & $\begin{array}{l}\text { Monoterpene } \\
\text { hydrocarbons } \\
\text { Oxygenated } \\
\text { monoterpenoids } \\
\text { Sesquiterpene } \\
\text { hydrocarbons } \\
\text { Oxygenated } \\
\text { sesquiterpenoids } \\
\text { Phenolic components }\end{array}$ & $\begin{array}{c}7.35 \\
\mathbf{8 0 . 3} \\
3.8 \\
0 \\
3.7\end{array}$ \\
\hline
\end{tabular}

\subsection{Results of the Antioxidant Activities}

The antioxidant activity of the essential oil of M. pulegium, has been evaluated for its DPPH radical scavenging activity. The oil reduced the stable, purple-colored DPPH radical to a yellowcolored DPPH-H with an $\mathrm{IC}_{50}$ value of $157 \mu \mathrm{g} / \mathrm{ml}$. Reduction of the DPPH absorbance was concentration dependent. Tocopherol (Vit E) and BHA (Butylated hydroxyanisole) and BHT(Butylated hydroxy toluene), which was used as a standard, showed an $\mathrm{IC}_{50}$ value of 15.5 $\mu \mathrm{l} / \mathrm{ml}, 22.5 \mu 1 / \mathrm{ml}$ and $180 \mu \mathrm{l} / \mathrm{ml}$ respectively.

Table 2. Antioxidant activity of aerial parts essential oils extracted by hydrodistillation (HD-EO) and other antioxidant references.

\begin{tabular}{c|r}
\hline Samples & $\mathbf{I C}_{\mathbf{5 0}}(\boldsymbol{\mu g} \mathbf{g} \mathbf{m L})$ \\
\hline HD-EO & 157 \\
(Vit E) & 15 \\
BHA & 22.5 \\
BHT & 180 \\
\hline
\end{tabular}




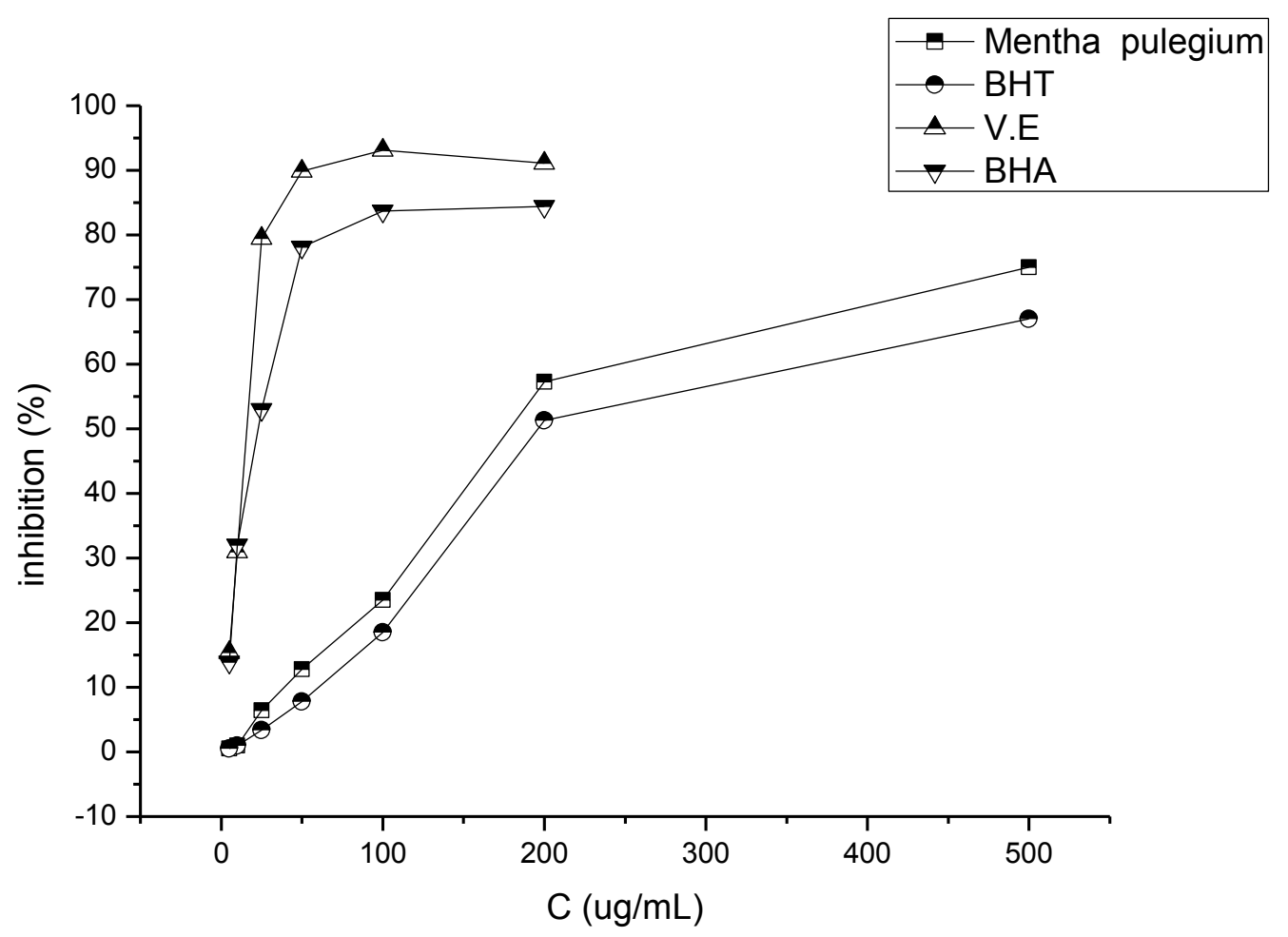

Fig. 1. Variation of the inhibition percentage of M. pulegium essential oil, BHT, Tocopherol (V.E) and BHA in relation to its concentration (DPPH test).

It is well-known that the antioxidant activity of plant essential oils containing terpenes is due to their capacity to be donors of hydrogen atoms or electrons and to capture the free radicals. DPPH

analysis is one of the tests, used to prove the ability of the components of the Mentha pulegium oil to act as donors of hydrogen atoms. The obtained results are shown in Figure 1 . The Mentha pulegium oil showed a significant effect in inhibiting free radicals produced by DPPH, reaching up to $75.4 \%$ at $500 \mu \mathrm{g} / \mathrm{ml}$ and $\mathrm{IC}_{50}$ value was found as $157 \mu \mathrm{g} / \mathrm{ml}$. This capability was decreased with the decrease of oil concentration 200 (57.3), $100(23.5), 50$ (12.8) and $25 \mu \mathrm{L} / \mathrm{ml}$ (6.4\%). These findings suggested that oil was able to reduce the stable free radical 2, 2-diphenyl-1picrylhydrazyl to the transparent diphenyl- picryl-hydrazine.

\section{CONCLUSION}

In order to prolong the storage stability of foods and to reduce the damage to the human body, synthetic antioxidants are used for industrial processing. But according to toxicologists and nutritionists, the side effects of some synthetic antioxidants such as butylated hydroxyanisole (BHA) and butylated hydroxytoluene (BHT) have already been documented. For example, these substances can show carcinogenic effects in living organisms [13,20]. From this point of view, governmental authorities and consumers are concerned about the safety of their food and about the potential effects of synthetic additives on health [21]. When compared to the antioxidative potential of the standard compounds used in this study (BHT, Tocopherol and BHA), essential oil of $M$. pulegium exerted strong antioxidant activity, which is almost equal to BHT in the DPPH system especially. On the other hand, further studies are urgently needed for better clarifying the cytotoxicity and other biological properties of the plant species presented here In conclusion, to drive health benefits from these highly effective natural antioxidants, their application in the dairy industry may be very valuable and desirable [22]. 


\section{Acknowledgement}

The authors gratefully acknowledge Mr Ali Tliba University of El Oued for his help and advice and the Technical staff in the laboratory of VPRS, Laboratory of Molécules Bioactive et Valorisation de la Biomasse, École Normale Supérieure, Kouba-Algiers and Laboratoire de Chromatographie, Faculté de Chimie, USTHB, Algiers, Algeria for their support.

\section{References}

[1] F. Naghibi, M. Mosaddegh, S. Motamed, and A. Ghorbani, "Labiatae Family in folk Medicine in Iran: from Ethnobotany to Pharmacology," Iran. J. Pharm. Res., no. 2, pp. 63-79, 2005.

[2] B. M. Lawrence, Mint: The Genus Mentha. CRC Press, 2006.

[3] M. B. Hassanpouraghdam, A. B. Akhgari, M. A. Aazami, J. Emarat-Pardaz, and others, "New menthone type of Mentha pulegium L. volatile oil from Northwest Iran," Czech J Food Sci, vol. 29, no. 3, pp. 285-290, 2011.

[4] J.-C. Chalchat, M. S. Gorunovic, Z. A. Maksimovic, and S. D. Petrovic, "Essential oil of wild growing Mentha pulegium L. from Yugoslavia,” J. Essent. Oil Res., vol. 12, no. 5, pp. 598600, 2000.

[5] M. Lis-Balchin and S. G. Deans, "Bioactivity of selected plant essential oils against Listeria monocytogenes," J. Appl. Microbiol., vol. 82, no. 6, pp. 759-762, 1997.

[6] W. Martindale, Martindale the Extra Pharmacopoeia, 31st edition. London: Amer Pharmaceutical Assn, 1996.

[7] X. C. Weng and W. Wang, "Antioxidant activity of compounds isolated from Salvia plebeia," Food Chem., vol. 71, no. 4, pp. 489-493, 2000.

[8] M. Naimiki, Antioxidants/antimutagens in food, vol. 29. CRC Crit Rev Food Sci Nutr, 1990.

[9] S. K. Kothari and U. B. Singh, "The effect of row spacing and nitrogen fertilization on scotch spearmint (Mentha gracilis Sole)," J. Essent. Oil Res., vol. 7, no. 3, pp. 287-297, 1995.

[10] L. Moreno, R. Bello, E. Primo-Yúfera, and J. Esplugues, "Pharmacological properties of the methanol extract from Mentha suaveolens Ehrh.," Phytother. Res., vol. 16, no. S1, pp. 10-13, 2002.

[11] V. K. Agnihotri, S. G. Agarwal, P. L. Dhar, R. K. Thappa, B. K. Kapahi, R. K. Saxena, G. N. Qazi, and others, "Essential oil composition of Mentha pulegium L. growing wild in the northwestern Himalayas India,” Flavour Fragr. J., vol. 20, no. 6, pp. 607-610, 2005.

[12] K. H. C. Baser, M. Kürkçüoglu, G. Tarimcilar, and G. Kaynak, "Essential oils of Mentha species from Northern Turkey," J. Essent. Oil Res., vol. 11, no. 5, pp. 579-588, 1999.

[13] B. N. Ames, "Dietary carcinogens and anticarcinogens oxygen radicals and degenerative diseases," Science, vol. 221, no. 4617, pp. 1256-1264, 1983.

[14] J. Barnes, L. A. Anderson, and J. D. Phillipson, Herbal Medicines: A Guide for Health-Care Professionals, 2nd edition. London: Pharmaceutical Press, 1996.

[15] N. L. and B., Addison Britton, An Illustrated Flora of the Northern United States, Canada and the British Possessions: Volumes III, 2nd edition., vol. 3, 03 vols. Charles Scribner's Sons, 1913.

[16] J. F. Clevenger, "Apparatus for the determination of volatile oil," J. Am. Pharm. Assoc., vol. 17, no. 4, pp. 345-349, 1928. 
[17] R. P. Adams, Identification of Essential Oil Components By Gas Chromatography/Mass Spectrometry, 4th Edition, 4th edition. Carol Stream, Ill: Allured Pub Corp, 2007.

[18] B.-M. Lue, N. S. Nielsen, C. Jacobsen, L. Hellgren, Z. Guo, and X. Xu, "Antioxidant properties of modified rutin esters by DPPH, reducing power, iron chelation and human low density lipoprotein assays," Food Chem., vol. 123, no. 2, pp. 221-230, 2010.

[19] M. Abdelhadi, A. Meullemiestre, A. Gelicus, A. Hassani, and S. Rezzoug, "Intensification of Hypericum perforatum L. oil isolation by solvent-free microwave extraction," Chem. Eng. Res. Des., vol. 93, pp. 621-631, Jan. 2015.

[20] P. Baardseth, "Effect of selected antioxidants on the stability of dehydrated mashed potatoes," Food Addit. Contam., vol. 6, no. 2, pp. 201-207, 1989.

[21] D. W. Reische, D. A. Lillard, and R. R. Eitenmiller, "Antioxidants," in food lipids. Chemistry, Nutrition and Biotechnology, New York: Marcel Dekker, 1998, pp. 423-448.

[22] C. Sarikurkcu, F. Eryigit, M. Cengiz, B. Tepe, A. Cakir, and E. Mete, "Screening of the antioxidant activity of the essential oil and methanol extract of Mentha pulegium L. from Turkey," Spectrosc. Lett., vol. 45, no. 5, pp. 352-358, 2012. 